\title{
Paclitaxel is the pharmacologic near perfect chemotherapy for peritoneal metastases
}

\author{
Paul H. Sugarbaker ${ }^{1}$, Kurt Van der Speeten ${ }^{2}$ \\ ${ }^{1}$ MedStar Washington Hospital Center, Washington, DC, USA; ${ }^{2}$ Department of Surgery, Hospital Oost-Limburg, Genk, Belgium \\ Correspondence to: Paul H. Sugarbaker, MD. MedStar Washington Hospital Center, Washington, DC, USA. Email: Paul.Sugarbaker@outlook.com; \\ Kurt Van der Speeten. Department of Surgery, Hospital Oost-Limburg, Genk, Belgium. Email: Kurt.Vanderspeeten@zol.be. \\ Comment on: Sugarbaker PH. Intraperitoneal paclitaxel: pharmacology, clinical results and future prospects. J Gastrointest Oncol 2021;12:S231-9.
}

Submitted Dec 16, 2020. Accepted for publication Mar 16, 2021.

doi: 10.21037/jgo-2020-21

View this article at: http://dx.doi.org/10.21037/jgo-2020-21

This manuscript by Sugarbaker pulls together the clinical data regarding intraperitoneal paclitaxel in a number of different diseases that manifest peritoneal metastases (1). The results of treatment are often positive even though the disease process is not specifically associated with a chemotherapy response to paclitaxel. The author suggests that the unusually favorable pharmacology of this drug accounts for its efficacy when used over time. As a cell-cycle specific drug, it greatly benefits from prolonged exposure times and/or repetitive IP applications (EPIC, NIPEC). Perhaps this is the only drug where "peel the onion" is a meaningful analogy for treatment of peritoneal nodules. Yes, nodules seem to respond, not only microscopic disease, as is the target for HIPEC and EPIC. Whether the NIPEC paclitaxel should be combined with systemic drugs, for example cisplatin, needs to be determined in the specific disease state being investigated. Finally, it should be mentioned that long-term intraperitoneal paclitaxel is well tolerated and few port problems are associated with the use of this drug. NIPEC paclitaxel is associated with benefit and needs to be fully explored.

\section{Acknowledgments}

Funding: None.

\section{Footnote}

Provenance and Peer Review: This article was commissioned by the editorial office, Journal of Gastrointestinal Oncology for the focused issue "Intraperitoneal Chemotherapy for Peritoneal Metastases: HIPEC, EPIC, NIPEC, PIPAC and More". The article did not undergo external peer review.

Conflicts of Interest: Both authors have completed the ICMJE uniform disclosure form (available at http:// dx.doi.org/10.21037/jgo-2020-21). The focused issue was sponsored by the Peritoneal Surface Oncology Group International (PSOGI). Drs. PHS and KVDS served as the unpaid Guest Editors of the focused issue. The authors have no other conflicts of interest to declare.

Ethical Statement: The authors are accountable for all aspects of the work in ensuring that questions related to the accuracy or integrity of any part of the work are appropriately investigated and resolved.

Open Access Statement: This is an Open Access article distributed in accordance with the Creative Commons Attribution-NonCommercial-NoDerivs 4.0 International License (CC BY-NC-ND 4.0), which permits the noncommercial replication and distribution of the article with the strict proviso that no changes or edits are made and the original work is properly cited (including links to both the formal publication through the relevant DOI and the license). See: https://creativecommons.org/ licenses/by-nc-nd/4.0/. 


\section{References}

1. Sugarbaker PH. Intraperitoneal paclitaxel: pharmacology,

Cite this article as: Sugarbaker PH, Van der Speeten K. Paclitaxel is the pharmacologic near perfect chemotherapy for peritoneal metastases. J Gastrointest Oncol 2021;12 (Suppl 1):S240-S241. doi: 10.21037/jgo-2020-21 clinical results and future prospects. J Gastrointest Oncol 2021;12:S231-9. 